\title{
The Approach of Children's Literature Towards Adjustmental, Emotional, Behavioral Disorders and The Bibliotherapy Method
}

\section{Research Article}

Elif AYDIN ${ }^{1}$, Nuran BASOGLU²

${ }^{1}$ Zonguldak Bülent Ecevit University, Turkish Language Department. Zonguldak, Turkey, ORCID: 0000-0001-6027-4431

${ }^{2}$ Zonguldak Bülent Ecevit University, Faculty of Education, Department of Turkish Education, Zonguldak, Turkey, ORCID: 0000-0001-7034-2629

To cite this article: Aydin, E., \& Basoglu, N. (2021). The approach of children's literature towards adjustmental, emotional, behavioral disorders and the bibliotherapy method, International Online Journal of Educational Sciences, 13(2), 502-520.

\begin{tabular}{ll} 
ARTICLE INFO & ABSTRACT \\
\hline Article History: & This study aims to present the strategies, techniques, and suggestions for psychological therapy and \\
behavioral improvement processes in children's books in the context of bibliotherapy approach. In \\
this study, 35 books which deal with adjustmental, emotional and behavioral disorders and \\
suggested solutions for these disorders were examined.The issues mentioned in 35 books and \\
inspirations, suggestions and practices were evaluated via document analysis method.. As a result of \\
content analysis, the 35 books were separated into three groups among themselves as books that \\
cover anxiety disorder, books that cover anger issues and books that cover other adjustmental, \\
emotional and behavioral disorders. In conclusion; it was identified that the most discussed topic is \\
an.04.2021 \\
aniety disorder among the books that cover "anxiety disorder", "anger issues" and "other \\
adjustmental, emotional and behavioral disorders" such as nail-biting, computer addiction, \\
twitching, jealousy, loneliness, boredom, sorrow, falsehood, complaining, perfectionism, constant \\
desire to be in the forefront, sleep problem. In most books, being in connection with good social \\
relations, sharing feelings, conducting various physical and mental activities stand out as important \\
suggestions emphasized for resilience. In the construction of the books, the own effort of an \\
individual is primarily brought to the fore in terms of the solutions of psychological issues and \\
getting help from an adult is proposed. It is only observed in a few books that consulting a \\
psychologist or an expert is placed in the middle of the construction of the work. In the books, \\
mothers and fathers are warned about especially making the child feel their love much more and \\
spending quality time.
\end{tabular}




\section{Introduction}

The science of psychology has always gone back to an individual's childhood and advocated that the traces acquired at childhood continue through life while protecting, empowering and healing adults' mental health; and this fact has brought children's mental health to a brand new dimension today. What is important is to prevent a child's problematic behaviors and difficult emotions from turning into disorders, in other words, to work on eliminating problematic ideas and behaviors.

At dealing with issues, the parents may also be insufficient and clueless in terms of problem solving methods. At this point, specially designed problem-oriented children books must be activated. Approaching problems like a therapist, nowadays children's literature has utterly different missions. Today, children's literature prioritizes a child's mental health and personal development. We can say that children's literature provides solutions to the problems which children confront especially at their everyday lives, it means to distract them from emotions, ideas and behaviors affecting their mental health in a negative way and moreover, intends to teach them to live with insoluble situations. And children's literature achieves these goals by means of psychological stories.

Reaching a scientific base of mutual study areas of literature and psychology started with Freud (Arslan, 2018: 226). It is not likely to think about literature and psychology independent from each other. We can make use of psychology which deals with analyzing human spirit in understanding the mood and personality of the characters in a literary work (Can, 2018: 8-9). Psychology bears the role of a compass in creating, evaluating and analyzing personalities of a literary work through the relationship between literature and psychology (Atl1, 2012: 257; Acehan, 2012:130). Psychoanalysis of protagonists in children's literature books is essential in terms of the fact that its target audience is special. Because, as Topçu (2019:20) mentioned that children identify the stories they listen with their own lives; they imitate the attitude of the characters they listen in their own experiences. The children identifying themselves with the protagonists and experiences in those stories could be more active at problem solving skills. According to Öncü (2012: 149), human beings learn through reading that they can face some traumas and fears in their lives. When an individual learns that he is not alone in this universe, he provides strength and hope to himself. Karagöz (2015: 488) overemphasizes that problemoriented children's books bring children together with multilayered problems of everyday life and traumatic experiences which children cannot make sense of or experience through literature.

In this study, children books handling problems on adjustment, emotions and behaviors that could possibly interrupt psychological strength of children are analyzed. Sayg1l (2004: 99-163) indicates tantrum, obesity, obstinacy, stealing, scolionophobia, fear, timidity, thumb sucking, enuresis, encopresis, aggression, lying, stuttering, tic, sleep disorder, night violence, masturbation, onychophagia and jealousy as behavioral disorders. Austin \& Sciarra (2019) define negativism, attention deficit and hyperactivity disorder, anxiety disorders (specific phobia, separation anxiety disorder, social anxiety disorder, post trauma stress disorder, extensive anxiety disorder, obsessive compulsive disorder), eating disorders, depressive disorders, bipolar affective disorder, suicidality, autism spectrum disorder, risky behaviors and emotional discomforts as emotional and behavioral disorders. Disorders regarding adjustment, emotions and behaviors which are discussed in this study include anxiety, anger, onychophagia, computer addiction, tic, jealousy, loneliness, sorrow, boredom, lying, complaining, perfectionism, narcissism and sleep disorder.

It is necessary to make use of bibliotherapy method in order to heal children by means of books. Bibliotherapy means reading written materials with a guide for understanding and solving problems on therapeutic needs of a person (Riordan \& Wilson, 1989: 506). "Bibliotherapy helps children express their feelings and also it is an interference that shows children how to handle these emotions" (DeVries \& Sunden, 2019: 135). The purpose of bibliotherapy is to encourage behavioral change in a normal way. Bibliotherapy means direct and intentional use of literary texts and psychotherapy together (Silverberg, 2003: 131). 
Bibliotherapy can be used in order to solve every day, ordinary problems which may appear at any time in a person's life as well as more intense and complex emotional problems at a psychological helping process (Öner, 2007: 136). According to Silverberg (2003: 132-133), bibliotherapy enriches the emotional and intellectual bond of adults with children; it helps adults take a step towards creating healthy relations. Bibliotherapy should be seen as a means for all children.

The benefits and functions of bibliotherapy are not limited to these. Reading experience takes us, helps us connect with others, reminds us the universality of human pain and hope and guides us on how to go on (Dajevskis et. al 2016: 35). Bibliotherapy is a strategy which enriches reading approaches and language skills by orienting children to personal and essential experiences with books (Jalongo, 1983: 796).

Bibliotherapy also helps students who have never experienced personal trauma develop empathy feeling (Dajevskis et. al 2016: 33). The purpose of using bibliotherapy is to help people get to know oneself and acquire inner vision by means of books (Öner, 2007: 136). Instructors can make use of bibliotherapy in teaching social skills for avoiding school failure as well as this method can help students overcome delicate issues (Prater, Johnstun, Dyches \& Johnstun, 2006: 5).

Today, bibliotherapy is accepted as a helping technique for individuals to solve their problems by means of books. It refers to build a dynamic relation between literary works and readers (Öner \& Yeşilyaprak, 2006: 560). According to Riordan \& Wilson (1989: 507), psychological research about the use of bibliotherapy has focused on almost only how to make highly qualified books and manuals unlike fictional or inspiring literature. The most explicit and consistent promise regarding effective use of bibliotherapy has come from the research on behavioral self-sufficiency (personal development). Dilidüzgün (2007: 78) states that for a child and a teenager, finding a similar world with similar problems in literary works doesn't mean finding a ready prescription to solve his problems. According to him, what is important is that the reader becomes more conscious about certain issues and similar realities are presented in different ways and with a multi-language approach. He also says that it is essential to be aware of the guiding spirit of the aforesaid books on personal and social development. Some books are included in the research as they explain how a person should read a book to a child. In this respect, it is discussed to use the books which contain such problem-oriented special themes in bibliotherapy method.

It is seen that in literature the books and studies to be used in bibliotherapy are limited. Arslan (2018: 226) determines that despite of the recent increase in psychological analysis of literary works, it has become weak in terms of quantity. Işıtan (2016: 471) emphasizes that there is an increasing interest in printing children books for the use of special purposes in our country, however, there are limited number of books on each theme and these books need to be analyzed by field experts whether they are suitable for child development or not. Akgün \& Karaman Benli (2019: 110) underline the need for presenting books to the field which are suitable to be used in bibliotherapy, based on the need for books containing themes such as "phobias", "separation anxiety", "adoption", "problematic behaviors" and "maltreatment". Öner \& Yeşilyaprak (2006: 564) highlight the idea that creating book lists on features and problems of child development will contribute to bibliotherapy studies substantially. All these findings presented by researchers have created a need for his study.

Based on the relevant research, it is proven that bibliotherapy can be used in developmental bibliotherapy (Akgün \& Karaman Benli, 2019) in order to support psychological strength (Topçu, 2019), to cure achluophobia (Lewis et. al. 2015), to acquire important values like cooperation and sharing (Uzman and Mağden, 2002) by using stories with pictures in children's literature books. In relevant literature it is also mentioned that poems can be used in bibliotherapy (Abbasoğulları, 2019), bibliotherapy can be included in class activities, which books would be suitable for different psychological disorders (Öncü, 2012; Dajevkis et. al. 2016; Leininger et. al. 2010; Prater et. al. 2006; Öner \& Yeşilyaprak, 2006) and children with behavioral or 
psychological difficulties can be affected directly (Işıtan, 2016; İlter, 2015; Karagöz, 2015; Turan, 2005; Scechtman, 1999).

Considering the relevant research, it is comprehended that all studies suggest the usability of bibliotherapy method based on the book suggestions that would be used with bibliotherapy method and studies which support and prove the effectiveness of the method.

\section{Method}

The study conducted a study on basic qualitative research, which is one of the research types. According to Merriam (2013); the main purpose here is to interpret and describe a fundamental phenomenon. This pattern is a type of conservation in education. It can form data observations, interview, observation or analysis. In order to determine the study group, a detailed examination was carried out by scanning the catalogs of publishing houses that write books for children. In this study, 35 books written for children and about adjustmental, emotional and behavioral disorders were chosen as the study group. The issues mentioned in 35 books and inspirations, suggestions and practices were evaluated via document analysis method. This study aims to present the strategies, techniques, and suggestions for psychological therapy and behavioral improvement processes in children's books in the context of bibliotherapy approach. Study data were acquired by data analysis of the chosen books. Data analysis involves the analysis of written materials that contain information on the phenomenon and phenomena to be studied (Yıldırım \& Şimşek, 2011: 187). Information acquired from study materials were displayed with content analysis. The purpose of such analysis is to gather similar data within the frame of certain concepts and themes and to enable interpretation by arranging them in a way for readers to understand (Yıldırım \& Şimşek, 2011: 227).

\section{Findings}

35 books about adjustmental, emotional and behavioral disorders were separated as three groups; "the books about anxiety disorder ( 15 books)", "the books about anger problem ( 8 books)" and "the books about other problems (12 books) and the findings were displayed as a table. In order for a better interpretation, the books in the same group are listed one under the other. 35 books are listed in the table in accordance with their theme, the problems they handle and the solutions they suggest.

Table1. Adjustmental, Emotional and Behavioral Disorders Mentioned in the Books and the Solutions Recommended

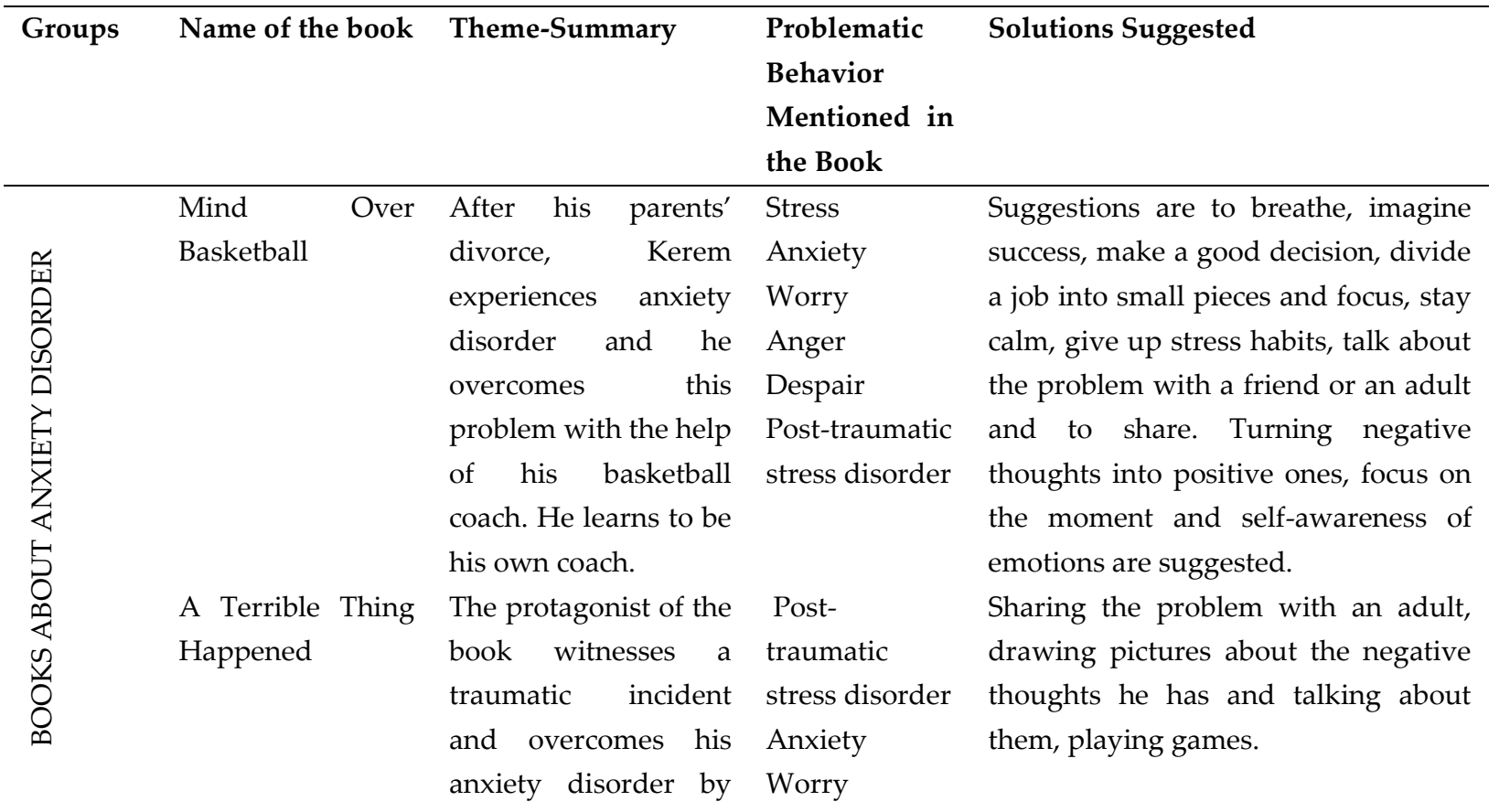


sharing his thoughts with an adult and by drawing pictures.

The Boy Who Built a Wall Around Himself

Mr. Worry
A Story About
OCD

The Goldfish Boy

The Worry Tree

A boy who had a trauma regains his psychological health by means of good friendship

What a child whose mind tries to control everything all the time feels and experiences; his despair and strategy to cope with these troubles

A boy feels guilty about his little brother's death and he has obsessive compulsive disorder for 4 years and experiences many troubles. Because of OCD (too obsessed to control and order everything) he finds the 15-months old lost child in his neighborhood and he overcomes this with the help of success feeling.

Juliet Jennifer Jones has trouble with stress management. She overcomes these worries with the help of a method which she learnt from her grandma when she was a little child. The name of the method is “Worry Tree"
Post-traumatic stress disorder and depression Alienation Lying Stealing and competition aggression

Obsessive

Compulsive

Disorder

Anxiety

disorder

\section{OCD}

Too rigorous

Obsessed with order and control Unrest Worry Uncontrolled knee tremble

Addiction to goods

Worry

OCD

Feeling of guilt Itches

Sorrow

Fight between siblings

Biting finger nails
Self-awareness of his own emotions, having conversations with someone about emotions and the problem, dancing, drawing, singing, playing games, sliding, swinging, climbing trees, having a good friendship

Suggesting that obsessive thoughts and anxiety are nonsense and he has the control of his mind, giving a name to his disorder, giving up compulsive behaviors step by step, leaving environment that increases fear (ex: quit watching horror movies), doing homework and fulfilling duties on time, giving up activities that are too tiring, doing sports (jogging, cycling), going to the doctor and taking medicine.

Breathing exercises, consulting to a psychotherapist, sharing fears with parents, self-confidence, giving up compulsive behaviors, doing other activities, using Cognitive Behavioral Therapy technique, Exposure Therapy and relaxation techniques

Repeating the sentence "I am capable of overcoming all kind of crisis", keeping your room neat and clean, describe your feelings When you feel angry, occupying your mind with different thoughts, hanging your worries on the branches of "Worry Tree" every night before sleeping, applying bandages on fingers to stop biting finger nails, trusting yourself 


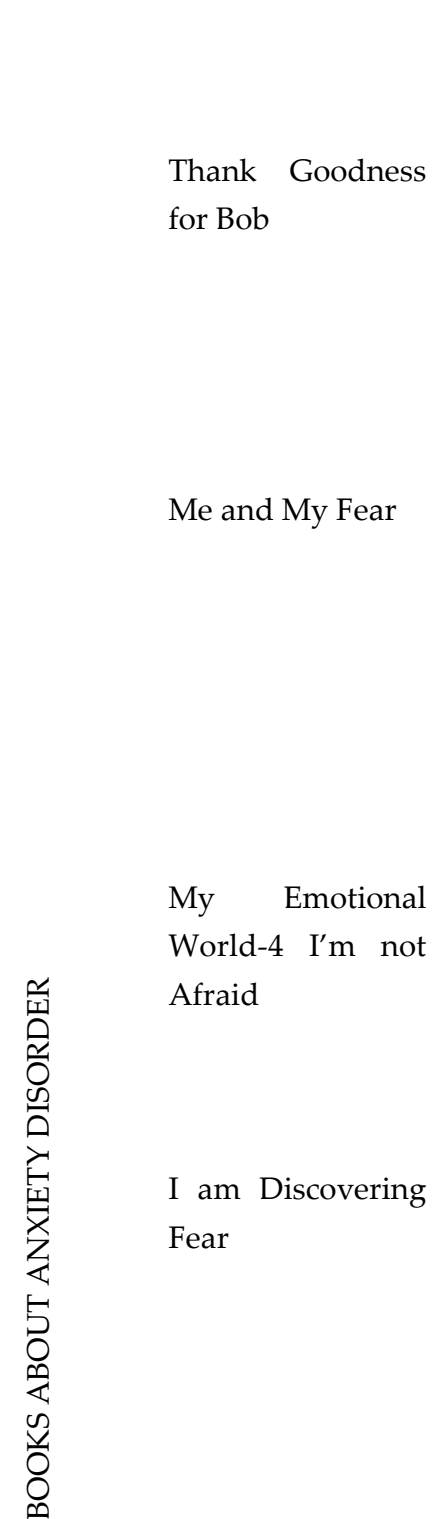

(hanging all the worries on a tree before going to sleep).

As Max worries about everything, he doesn't enjoy himself. He gets rid of these worries with the help of the interaction he has with his dog.

A little girl is dealing with the fear she feels all the time and then she overcomes this feeling

A child is afraid of dark, communicating with guests, cycling, dogs, fireworks and he learns to overcome these fears

Kerem doesn't enjoy life because of his dense fear and he learns strategies to overcome fear
The Wall in the Middle of The Book
Fears and prejudices are not things to get rid of, instead they protect us. On the other hand, the things we think they are safe turn out to be dangerous.

It Hurts When I Ege can't acquire a poop! healthy toilet habit as he is afraid of both pooping and sitting on a toilet seat. Ege gets help from a doctor, learns the source of the problem against the problems, take a tough stance

Worry

Disorder

Having conversation or chatting on a problem with a friend or an animal, accepting everything as they are

Fear

Worry

Inner voice

talking about

negative

things all the

time

Fear
Worry
Fear
Not enjoy life

Turning on the light against the fear of dark, communicating with people, work on your goal with the help of an adult, stay calm

Sharing fear with parents, drawing the things you fear, getting help from school counselor, self-awareness of your feelings and staying calm, leaving an atmosphere, visualizing, imagining that you have a remote control and mute scary things, making an emotion thermometer, writing a farewell letter to your fears and throwing them into "Fear Dump", drawing a super protagonist who can cope with all the fears

Confronting fears and worries
Toilet problem fear
Explaining how poop occurs in our body with pictures and stories, teaching the right food that soften poop, practicing 5-step poop programme: watch out your food, animating poop while coming out, gutbucket exercise, follow the poop, reward yourself 
and overcomes the

fear.

Teo's Poop Book

A child can't acquire healthy toilet habit; instead, he poops in his diaper. His parents explain him the fooddigestion cycle in our body with pictures in a book and he overcomes it.

The Flyaway Based on the blanket Blanket metaphor, children attribute their love for parents to the objects they like and when they have to leave these objects, they get upset as if they leave their parents.

Teo's Book of Teo finds it boring to Night Fear sleep and he is afraid of sleeping. He gets rid of this fear with the help of his mother

Do I Have the To make children Right to Hit Others?

Chillax!

What is Violence?

think about violence,

to create new

approaches by

generating new

questions on these

questions and

presenting solutions

When Mert is angry,

he overreacts and

does things that he

regrets and apologizes

for. He does this again

and again. Then, with

the help of his school

counselor, he

overcomes this

problem by practicing

relaxation and chilling

exercises.

To make children

Violence

Anger

Aggression

Self-control

Self-hatred

Being exposed

to peer

mocking

think about violence, Anger

to create new (Mocking

approaches by Selfishness

generating new Grumpiness)

questions on these
Explaining how poop occurs and if poop stays in our system, it is stuck in our guts and causes stomachache, placing a suitable toilet seat for the child who is afraid of falling into the toilet

Softening separation by singing and speaking with a soft voice, suggesting that they will rejoin again, not staying separated for too long and too distant so that the child would know they can rejoin again

Finding the source of the fear with the help of the parents, drawing pictures of the things you are scare of, even making fun of the pictures

Finding the source of anger instead of being aggressive, learning to control your feelings, accepting that life and people can't be as we want them to be all the time, trusting ourselves and other people, going to law if necessary

Understanding our feelings and finding the source of our anger, practicing anger management strategies- croon, leave that place, imagine yourself laughing loudly, put a smile on your face, cover your face with your hands- sharing your problems, practicing breathing exercises, imagining, doing sports, keeping a diary, watching entertaining programs, walking in the sun

Accepting that violence is a part of life but not denying the pain caused by violence, talking to parents about avoiding violence, staying alone and think, taming the violence tendency in yourself, keeping freedom and peace, 


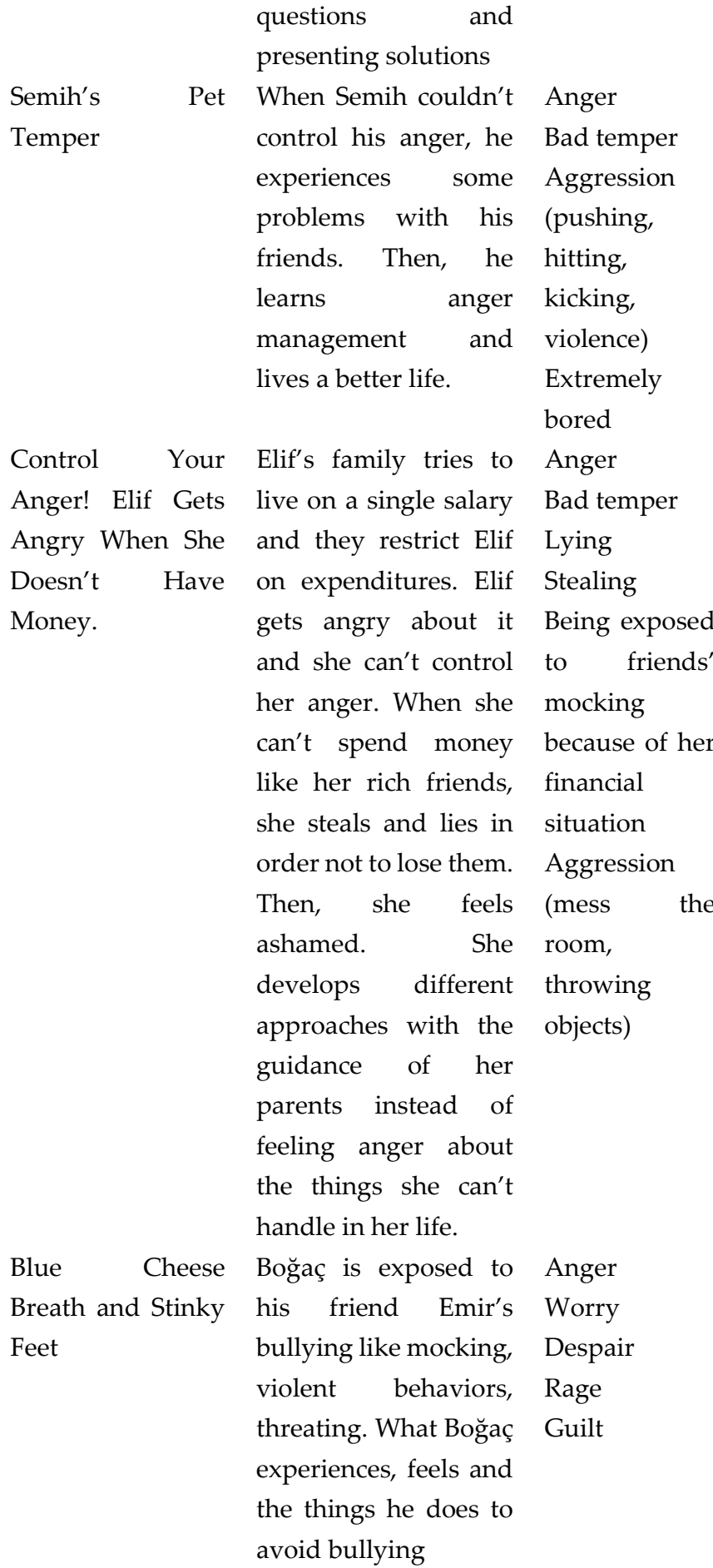

Teo's Book of Teoman is exposed to Bullying result of the a group of friends' bullying like mocking, spoiling game, ignoring, humiliation, feeling worthless, excluding and isolation. With his thinking on the situations that may create violence.

It is suggested that the only thing anger can make is to create problems. It is comprehended that if you can't control your anger, no one can do. It is suggested to count to 10 , to read the alphabet backwards, to take a deep breathe in and breathe out slowly during an anger crisis.

Parents treat their child tolerantly and more affectionately. They raise awareness of their child by talking to her about the wrong behaviors she has. Developing different point of views on Money:

1. There will always be better things than you have-clothes, house, money etc. You should love your possessions and do shopping wisely.

2. There will always be people who make fun of you because of your inabilities. Ignore them and stay away the people who want to upset you.

3. Calm down when you get angry.

Staying away from bullies, ignoring bullies, suggesting that you are strong, getting help from someone (a friend, teacher or parent), even staying together with friends against bullies, speaking with bullies not with kind request words but with clear claim words, making wise subtle humor instead of teasing screaming as loud as others can hear you if the bully goes on bullying you, practicing the right reactions at home with parents and showing that you are not afraid

Anger (as a bullying being exposed to)

Rage

Sorrow

Crying jags
Talking about problems with the father, suggesting yourself that you are strong, overcoming bullies as if it is a game, ignoring, responding wisely without showing your emotions, getting help from an adult, controlling anger, increasing your emotional strength, spending time with friends, 
father's motivational

talk and strategies, he learns to cope with bullying.

Teo's Mocking When Teo can't play

Book

basketball well, his friends make fun of him. He gets angry, cries a lot and uses violence against friends. With his mother's help, he manages his anger, changes his views and learns to cope with verbal violence he is exposed to.

Teo's Nail Biting A child is tired of Book being warned about his habit of biting nails. Although he wants to give up this habit, he is not able to do it. Then, with the help of his grandpa, he manages to give up this habit.

Teo's Tablet Book Teo is addicted to games and this addiction is harmful for him. He overcomes this addiction by spending more and quality time with his family and doing different activities.

My Emotional different

A child is jealous of World- 3 I'm not his friends' new Jealous belongings, their
Biting nails

Anger as a result of verbal bullying

Being exposed to mocking

Failure

Shame

Crying jags

practicing at home, not getting demoralized, knowing that there will always be challenges and you have to overcome them.

Leaving a place when you get angry, talking about problems with mother, not believing everything you hear or exaggerating, writing down your emotions as a table (preparing a table with sections of events, emotions, thoughts and behaviors), not showing any reaction when you get angry, changing your way of thinking, developing awareness about that making fun of others is wrong, focusing on points you are good at, going on playing even if they make fun of you.

Chatting and feeling empathy, identifying the source of the habit and eliminating that need, getting rid of the habit

By means of the child's favorite sport (football) overcoming the problem (in this method, when your nails grow and your wounds heal, you score a goal to your opponent. Although your opponent advises you to bite your nails, you should ignore him.) Putting a plan with 3 tactics into action: 1st tactic: Defense-apply plasters on each finger, 2nd tactic: Distraction- find activities to use your hands (playing with play dough, squeezing a small ball in your hand, making a necklace by stringing beads, making cookies with mum, doing puzzles), 3rd tactic: More activities- going to the park, playing with a ball, riding a bike.

Addiction to Deciding on a specific time period for computer games and stick with it, changing this games (sleep time period in order not to become problem, fear habits, shortening this period of time, of night, not taking the tablet back if the child enjoy life, doesn't obey the rules, spending more divergence, and quality time with family, alienation, canalizing the child to more enjoyable have hallucination) and active games (for example; the floor is lava, treasure hunt...) Developing a suitable point of view instead of problem-oriented thinking (ex: thinking that little sibling needs 


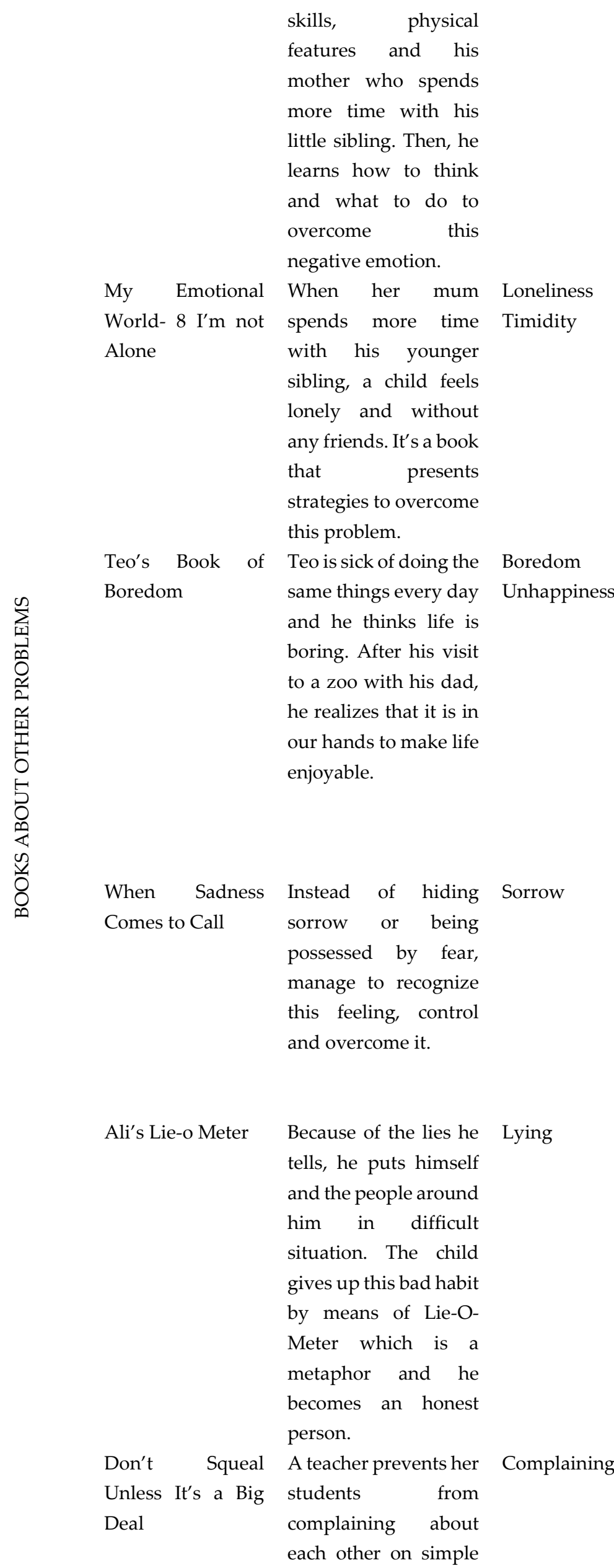

more maternal care, remembering that your mother used to spend more time with you when you were younger), spending more time with your little sibling, not comparing yourself with others, sharing the happiness of others, being satisfied with what you have, finding your own talents and trying to improve them.

Making friends, sharing feelings with friends, taking the first step for playing games, reminding himself that it is a temporary situation and spending time with little sibling

Recognizing your feelings by means of games (playing "What are you happy about?" "What are you sad about?" game at night before sleeping), spending more and quality time with parents, doing favorite activities with friends (playing football), doing the relevant activity to enjoy life (for example: you can enjoy sea by swimming and enjoy school by joining friend groups.)

Giving a name to sorrow, understanding its reason, doing activities that make you feel good (drawing pictures, listening to music, drinking hot chocolate, going out, taking a walk...), accepting fear as a friend or a guest instead of being scared and exaggerating it.

Being patient with the child, making him understand that what he does is wrong, giving reasonable punishments, child's explaining his lie to his parents, being proud of the child who confesses his lie, making the child promise that he won't lie again.

Asking students to try to solve problems among themselves, telling teacher only the problems that are unsolved or important (being injured, 
things by setting up some rules in class.

The Girl Who Doesn't Make Any Mistakes

Selin Sore Loser

The Rabbit Who Wants to Fall Asleep I Can't Stop!-A Story About

Tourette Syndrome
Betül struggles to be perfect and do everything completely on time. Then, she gives up this habit and she becomes a more peaceful and happier person.

Selin always wants to be the winner and she doesn't accept to lose so he becomes upset and aggressive. She gets rid of this habit with the help of her teacher.

Roger, the rabbit that has trouble to fall into sleep, and the child who is listening to the story go on a journey together- when the reader calls his name. He can fall into sleep by means of the relaxation instructions in the book.

A child who suffers from tics has problems in his social environment and his struggle to overcome them. hurting someone or destroying a public material, etc.) and asking students to obey the rules "Don't Shout and Don't Complain If It Is Not Important".

Perfectionism Accepting mistakes, laughing at your mistakes, let things slide.

Not enjoy life

Not tolerate to lose

Always want to be the winner

Anger

Rage

Rude

behaviors

Sleep problem

Falling into sleep by means of psychological relaxation while listening to the story, reader's yawning while reading the book, often suggesting that his eyelids are getting thicker, repeating words about falling into sleep and the listener's name are some techniques which quickens falling into sleep.

Tics and the feelings they cause (unrest, worry, anger, timidity, rage)

Occupying yourself with something else, doing sports (swimming, basketball), not hiding the illness, making good friendship, ignoring people laughing at you, focusing on success, creating a painting that explains the time and situations causing your tic, not making fun of people with tics.

It is seen that the most common subject in the books is anxiety disorder. Thus, 15 books out of 35 books mention about adjustmental, emotional and behavioral disorders. Among these books, Mind Over Basketball, A Terrible Thing Happened and The Boy Who Built a Wall Around Himself mention about post-trauma stress disorder. Three books, Mr. Worry A Story About OCD, The Goldfish Boy and The Worry Tree are about obsessive compulsive disorder. Five books, Thank Goodness for Bob, Me and My Fear, My Emotional World-4 I'm not Afraid, I am Discovering Fear, The Wall in the Middle of The Book mention about generalized anxiety disorder. In two books, It Hurts When I poop! and Teo's Poop Book toilet problem and fear issues are handled. The book, The Flyaway Blanket, is about separation fear. In the book, Teo's Book of Night Fear, sleep disorder issue is discussed. 
The most mentioned topic after anxiety disorder is anger management in 8 books. 3 books out of 8 (Blue Cheese Breath and Stinky Feet, Teo's Book of Bullying and Teo's Mocking Book) mention about anger problem as a result of being exposed to physical or verbal bullying. In the book, Control Your Anger! Elif Gets Angry When She Doesn't Have Money, by mentioning about uncontrolled anger caused by poverty, anger issue is tied to a specific reason.

Other books discuss themes such as nail biting, computer addiction, jealousy, loneliness, boredom, sorrow, lying, complaining, perfectionism, always wanting to win, tic and sleep problem.

It is witnessed that many issues are discussed together, emotional and behavioral disorders are intertwined in the books. In the book Teo's Book of Night Fear sleep problem is discussed; however, sleep problem is caused by anxiety disorder so, it is categorized under the title of anxiety disorder. In the book The Worry Tree which mentions about anxiety disorder, nail biting habit is also included. While grouping books, the main problem in the book is considered. The book, Selin Sore Loser, is about a character who can't stand losing, who wants to be in the spotlight all the time and if it doesn't happen she gets furious. Although the book discusses anger problem, the main problem is that she always wants to win. Thus, it is not considered among the books about anger management but in other problems group.

In the books about anxiety disorder, sharing and friendship seem to be the mutual solution. Another subject highlighted is staying away from boredom, in other words, occupying yourself with various physical and mental activities. There are different kinds of activities in different numbers. Remote control, emotion thermometer, letter, worry tree activities are some of them. Among the activities, drawing pictures is recommended strongly. Overcoming negative thoughts and emotions by giving names to emotions like worry and fear, drawing pictures of negative emotions and even making funny pictures of these emotions are discussed in most books. In Teo's Book of Night Fear, Teo draws the monster he is scared of and by this way he realizes that his fear decreases. Then, he makes the picture funnier and overcomes his fear to a great extent. In I am Discovering Fear, Kerem is shy about explaining his fear and on his mother's suggestion he draws the creature he is afraid of and gives it the name "Snappish Horned Dragon". They add hair, moustache, a hat and a fire extinguisher to the creature on his father's suggestion and these additions make it funny. In activities section of My Emotional World-4 I'm not Afraid, while drawing fears is suggested, it is seen that these negative emotions are embodied by means of pictures also in the books. In When Sadness Comes to Call and Me and My Fear the writers embody negative emotions as a cloudlike entity.

The books contain some relaxation techniques such as imagining in mind, cognitive behavioral therapy, exposure therapy, confrontation, suggestion and gradual adaption. It is stated that for problems regarding toilet education, using pictures and stories is useful to explain children how poop occurs. For separation anxiety, suggestion and gradual adaption work. Despite it is indicated that suggestion is useful for sleep problem, confrontation is recommended for situations regarding fear.

In order to solve psychological problems, it is underlined to be aware of one's emotions, to recognize and accept them because a person who is aware of his own emotions can talk about them and relax while communicating. The activities (imagining in mind, worry tree, etc.) presented in the books are also relevant to displaying emotions and healing, letting positive feelings settle and negative feelings fly away. Being wellaware of emotions is essential in terms of taking advantage of these activities.

In the books about anger management, trying to find the source of anger primarily is recommended as the preferred solution. Some strategies for anger management like breathing exercises, suggestion (such as being satisfied with what you have and get), imagining in mind, talking and communicating are presented. Peer bullying is also discussed in the books as one of the challenging problems for children. Not only helping solutions for anger management are presented but also some recommendations on how to treat a bully are 
indicated. Rehearsing the behaviors against a bully at home and animating the situation by turning it into a theatre play are remarkable practices.

A practitioner of literature uses the devices in literary texts such as metaphor, simile and allegory in discussions to facilitate and enhance the efficacy of psychotherapy (Silverberg, 2003: 131). In many books it is seen that including metaphors could strengthen the fiction. In The Boy Who Built a Wall Around Himself, a child isolates himself from other people and stops contacting with them after a trauma; and his reactions are metaphorized by "wall and brick". In the book The Wall in the Middle of The Book, wall is a metaphor for prejudices. In Ali's Lie-o Meter, "lie-o-meter" machine is used as a metaphor for detecting the child's lies. In Mind Over Basketball, strategies on how to cope with stress in every field of our lives is metaphorized by "basketball coach". Just as it is possible to be good at basketball with the instructions and help of a basketball coach, in real world we can develop skills to overcome problems in our lives by being our own life coach. In The Flyaway Blanket, the strong bond between the child and the parents and the difficulty of separation is metaphorized by the love of "blanket". In the book When Sadness Comes to Call, sorrow is embodied as a huge green ogre. It is hinted that by embodying sorrow, one should greet and accept it as a guest.

Some nicknames such as "The Girl Who Never Makes Mistakes, Blue Cheese Breath and Stinky Feet, Mert Who is Ready to Burst (Chillax!), Selin Sore Loser" are remarkable in the books. These repressive nicknames were given to the protagonists of the books by their friends or the people around them regarding the psychological problems they have in the fictions. When the problems solve, the nicknames are no longer pronounced at the end of the books.

In general, some suggestions like relaxation with breathing exercises, doing sports, sharing with family members and making friends are presented to the readers in most of the books to control and manage feelings. In order for psychological strength, the importance of having good affairs with people and sharing feelings is underlined in every opportunity. Through these books, the message that being in communication is essential regardless of the kind of problem is given. The person with whom the child interacts with could be a basketball coach, an adult, a teacher, a school counselor, a friend, grandpa, grandma, one of the parents or both of them or even a dog. A healthy relation with a creature who is trusted and makes you happy is presented as the key solution to all problems in the books. However, the suggestion that you should be the one solve your problems in any case is placed in the fictions. It is seen that an expert is included into the solution process of a problem only in the fictions of the books The Goldfish Boy, It Hurts When I poop! and I Can't Stop!-A Story About Tourette Syndrome. Although consulting a psychologist or a doctor isn't placed in the books except these ones, it is recommended to get help from a psychologist or a doctor in case of not overcoming the problem in the relevant information section of most books.

The books analyzed in this study are sources to be applied for bibliotherapy as they guide us in terms of practicing the strategies given both intertextual and nontextual and with their appendixes working as a guidance book which teaches the ways to overcome problems. It is observed that all recommended solutions regarding negative thoughts or unwanted behaviors are explained in the notes section at the end of the books even though they aren't included in the fiction. For example, in the fiction of Control Your Anger! Elif Gets Angry When She Doesn't Have Money, there is no refer to breathing exercise or doing sports but these recommendations are placed in the tips section at the end of the book. "Note to Parents and Educators" section in 24 books, not only solution strategies in the fiction of books are handled in detail but also other strategies that aren't placed in the fiction are explained. It is seen that materials related to the games, activity sheets and also links to get prints for activities are provided in appendix section. There is no guiding information only in the books Thank Goodness for Bob, The Goldfish Boy, The Wall in the Middle of The Book, When Sadness Comes to Call and The Girl Who Doesn't Make Any Mistakes. 
Determining the age groups which the books are suitable for makes it easier to use bibliotherapy method. In 13 of the books analyzed, there is information on which age level they are suitable for. It is observed that the books are for 2-13 age level. In this respect, it is obvious that age limit of children's literature is taken into consideration. There are books which can be read at an age level starting from pre-school period to the end of primary school period, in other words, early puberty stage.

It is possible to mention about three stages for the solution of problems in most of the books: $1^{\text {st }}$ stage; the child is exposed to a problem; s/he is alone with the problem for a while and tries different methods to overcome it. $2^{\text {nd }}$ stage; $s /$ he gets help from family, teachers and an adult. $3^{\text {rd }}$ stage; if the support, guidance and strategies of the elders aren't enough, s/he consults a psychologist or an expert. In many of the books analyzed, even though the problem is solved without the need for going to a psychologist, it is strongly recommended to get help from a psychologist if the problem isn't solved in "Note to the Adults" section at the end of the books.

26 out of 35 books which mention about emotional and behavioral disorders belong to foreign writers and 9 books belong to Turkish writers. 8 out of 9 books belong to Teo series, and 1 of them belongs to $I$ am Discovering Fear and Ordinary Unordinary Things Series. In most of the books translated from English, Turkish names are preferred instead of original names of protagonists (Semih's Pet Temper, Elif Gets Angry When She Doesn't Have Money, Selin Sore Loser, and Ali's Lie-o Meter). It is possible to think that this translation is preferred for making it easier for children to identify themselves with the protagonist.

It is indicated that 24 books out of 35 books which are analyzed as they interfered in certain and special themes, special behavior and thinking manners are approved by institutions such as APA, Madalyon Psychology Centre, IBS (Institute of Behavioral Sciences), Child and Youth Psychological Center or experts. Writers of some books are either an expert or a psychologist.

Suggestions, solution recommendations, problem solving stages in the books that are written for a specific purpose are provided without using a didactic, critical or judgmental language. Only in the books $I$ Can't Stop!-A Story About Tourette Syndrome and The Goldfish Boy, there are some scenes in which family members can't be patient from time to time. This situation is undistractedly rare and in fact, it shows how important the books are for the ones who seek for a solution and the ones who struggle with such problems.

As the books being analyzed in the study serve for a specific purpose, chatting on the book with an adult and reading the book with an adult would increase the benefits expected to get from the book. It would accelerate the solution if an adult guides the process or even is included in the process of practicing the activities. As the events being told in the books such as The Wall in the Middle of The Book, The Boy Who Built a Wall Around Himself Me and My Fear, When Sadness Comes to Call and The Flyaway Blanket are fictionalized abstractively, it is inevitable to read especially these books with the guidance of an adult in terms of bibliotherapy to reach its goal.

\section{Discussion, Result and Recommendations}

Today children's literature not only has taken on an important task but also has undertaken a new mission as prioritizing and protecting psychological strength of children by means of children books that are fictionalized with mental disorders or difficult emotions. By analyzing the books in terms of both content and additional data, this study has served to introduce the books that are indicated as a deficient part of the literature.

Karagül (2018: 50) infers that the most effective practice in bibliotherapy process is having conversation with children about the book being read. The thinks that the questions being asked while reading a book can help to detect the psychological state of a child; and it is necessary to detect the effect of that book on the child 
in order to make use of bibliotherapy by means of re-fictionalizing and changing activities after having read the book. 35 books being analyzed not only enable to chat with children but also give children a chance to draw their feelings, get to know their emotions through games and reveal their feelings; and they function as a therapist who saves children from negative emotions with the help of these activities.

Ilter (2015) detected that bibliotherapy-based program which he developed for gifted children has decreased the perfectionism level of students' siginificantly. In this respect, it is possible to make use of the book The Girl Who Doesn't Make Any Mistakes in bibliotherapy based programs. It is comprehended that in bibliotherapy exercises which are practiced with identification, refinement and inner vision stages, it is highly significant to meet children with the right books in terms of content and the character at the right age level in order for reaching psychological strength by acquiring adjustmental, emotional and behavioral change. In his study analyzing theme distribution of children's books written for specific purpose, Işıtan (2016) revealed that the most discussed theme was "problem behaviors" and the most discussed theme among them was fear. He also stated that nail biting, sleep problems, lying, timidity and anger management themes were less discussed compared to it. It is seen that the findings match with the results of this study except for "anger" theme. Likewise, the number of the books mentioning about anger problem in this study ranked number two as the most discussed theme in general distribution. In his study where he used bibliotherapy method in group therapy practices as the primary interference procedure on five young boys who have aggressive characters, Shechtman (1999) found that all five students showed less aggressive behaviors. Moreover, the study indicated that there is an increase in constructive behaviors for all participants in the group. In this study, the works mentioning about anger problem can be the subject of practice in order to provide anger management and prevent aggression.

As a result of the study analyzing the effectiveness of bibliotherapy treatment for little children who have specific darkness phobia and who are afraid of sleeping alone, Lewis and others (2015) expressed that there is a decrease in the level of darkness fear of children. It is recommended to use My Emotional World-4 I'm not Afraid and Teo's Book of Night Fear for similar purpose.

Leininger and others (2010) recommended 10 children's literature books which contain characters with OCD. In their study Prater and others (2006) presented a 10-step process to practice bibliotherapy in class and a list of children books that could be used in bibliotherapy. The study was original in terms of presenting an analyze list for those who wish to exercise bibliotherapy practices.

Children's books written for specific purpose can help children who are unhappy, stressed and desperate because of their anxieties and temper tantrums they can't cope with for feeling that they are not alone, understanding that they can get rid of the feeling and making progress with solution suggestions. Furthermore, these books can also contribute to change the profile of today's children who always want to be in the spotlight, who don't know how to enjoy life without showing uncontrolled competitiveness even in the games and who are result-oriented. They teach children to obey rules and to do their best instead of trying to be perfect; also, they guide children to protect their self-control instead of showing anger on every occasion and to express their emotions in the most correct way.

Based on the books analyzed, it is predicted that the use of books mentioning about adjustmental, emotional and behavioral disorders as a new approach of children's literature by parents at pre-school period and by teachers at schooling period with bibliotherapy method can be useful for children who experience problems caused by certain disorders and illnesses. It is also predicted that children can overcome these problems and the negative feelings and thoughts resulted from these problems by means of literature, and even though the state of disorder doesn't disappear completely, they can learn to cope with this situation. The books help to provide mental treatment regarding the disorders discussed in the books. Through these books, children can confront their own problems and they can find new solutions to their problems, acquire a new 
perspective by identifying themselves with the protagonist in the book. These books enable children to understand their feelings and to be informed about the relevant issue, and also they provide practical solution suggestions to children.

In conclusion, the books analyzed in the study guide children on how to sort out the problems they confront without turning them into a trouble, in other words, they serve as a kind of therapist. They lead children to speak comfortably even in the most difficult and delicate situations. Children's literature discussing adjustmental, emotional and behavioral disorders will serve greatly as a guide not only for children but also teachers, parents, social service workers whose target population is children, therapists, pedagogues and psychologists. 


\section{REFERENCES}

Abbasoğulları, G. (2019). İbrahim Hakkı Hazretleri'nin şiirlerinin biblioterapi bağlamında değerlendirilmesi. Trabzon Ilahiyat Dergisi, 6(1), 397-427.

Acehan, A. (2012). Fahim Bey ve Biz, Anayurt Oteli ve Aylak Adam romanlarına psikolojik bir bakış. Motif Akademi Halkbilimi Dergisi, 5(10), 128-152.

Akgün, E., \& Karaman Benli, G. (2019).Bibliotherapywith preschool children: a case study. Psikiyatride Güncel Yaklaşımlar-Current Approaches in Psychiatry, 11(1), 100-111, https://doi.org/10.18863/pgy.392346

Arslan, A. (2018). Edebiyat ve psikoloji kavşă̆ında Nihan Kaya'nın eserleri. (Yayımlanmamış yüksek lisans tezi). Giresun Üniversitesi Sosyal Bilimler Enstitüsü Türk Dili ve Edebiyatı Ana Bilim Dalı Yeni Türk Edebiyatı Bilim Dalı, Giresun.

Atlı, F. (2012). Edebi metnin ve yaratıcılığın kaynağına ulaşan yol: psikanalitik edebiyat eleştirisi. Turkish Studies, 7(3), 257-273.

Austin, V. L., \& Sciarra, D. T. (2019). Çocuk ve ergenlerde duygusal ve davranışsal bozukluklar. (Çev. M. Özekes). İstanbul: Nobel Akademik Yayıncılık. 1. Basımdan Çeviri.

Can, Y. (2018). Edebiyat psikolojisi bağlamında Hikmet Erhan Bener'in Kedi ve Ölüm ile Acemiler adlı romanlarındaki savunma mekanizmalarının incelenmesi. (Yayımlanmamış yüksek lisans tezi). Marmara Üniversitesi Türkiyat Araştırmaları Enstitüsü Türk Dili ve Edebiyatı Anabilim Dalı Yeni Türk Edebiyatı Bilim Dalı, İstanbul.

Dajevskis, E., Cappiello, M. A., \& de Galarce, P. C. (2016). Therapy by the book. School Library Journal, 62(10), 32-35.

DeVries, D., \& Sunden, S. (2019). Bibliotherapy with children who have a sibling with a disability. Journal of Poetry Therapy The Interdisciplinary Journal of Practice, Theory, Research and Education 32(3), 135-155. https://doi.org/10.1080/08893675.2019.1625147

Dilidüzgün S. (2007). Öğreticilik sorunu bakımından Ayla Çınaroğlu'nun çocuk kitapları. Çocuk ve Gençlik Edebiyatında Ayla Çınaroğlu Sempozyumu içinde (139-145. ss.). Eskişehir.

Jalongo, M. R. (1983). Bibliotherapy: literature to promote socio emotional growth. The Reading Teacher, 36(8), 796-803.

Işıtan, S.(2016). Özel amaçla yazılmış çocuk kitapları. Turkish Studies, 11(4), 471-492.

İlter, B. (2015). Bibliyoterapi tekniğinin üstün yetenekli çocuklarm mükemmeliyetçilik düzeylerine etkisi. (Yayımlanmamış yüksek lisans tezi). Fatih Sultan Mehmet Vakıf Üniversitesi Sosyal Bilimler Enstitüsü Psikoloji Anabilim Dalı, İstanbul.

Karagöz, B. (2015). Kendilik değerini koruma bağlamında çocuk edebiyatı eserlerinin kullanımı. Uluslararası Sosyal Araştırmalar Dergisi, 8(40), 486-493.

Karagül, S. (2018). Çocuk edebiyatı ve bibliyoterapi. Çocuk ve Medeniyet Dergisi, 3(6), 43-55.

Leininger, M., Dyches, T. T., Prater, M. A., Heath, M. A., \& Bascom, S. (2010). Books portraying characters with obsessive-compulsive disorder top 10 list for children and young adults. Teaching Exceptional Children, $42(4), 22-28$.

Lewis, K.M., Amatya K., Coffman, M. F., \& Ollendick, T. H. (2015). Treating night time fears in young children with bibliotherapy: evaluating anxiety symptoms and monitoring behavior change. Journal of Anxiety Disorders, 30, 103-112. https://doi.org/10.1016/j.janxdis.2014.12.004

Merriam S. B. (2013). Nitel araștırma: desen ve uygulama için bir rehber. (C,ev. Ed.: Selahattin Turan.). Ankara: Nobel.

Öncü, H. (2012). Bibliyoterapi yönteminin okullarda psikolojik danışma ve rehberlik amacıyla kullanılması. Türkiye Sosyal Araştırmalar Dergisi, 16(1), 147-170.

Öner, U. (2007). Bibliyoterapi. Çankaya Üniversitesi Fen-Edebiyat Fakültesi Journal of Arts and Sciences, 7, 133-150. 
Öner, U., \& Yeşilyaprak, B. (2006). Bibliyoterapi: psikolojik danışma ve rehberlik programlarında çocuk edebiyatından yararlanma. II. Ulusal Çocuk ve Gençlik Edebiyatı Sempozyumu Bildiriler Kitabı içinde (559-565.ss.). Ankara Üniversitesi Eğitim Bilimleri Fakültesi Yayını.

Riordan, R. J., \& Wilson, L. S. (1989). Bibliotherapy: does it work?. Journal of Counseling Development, 67(9), 506-508. https://doi.org/10.1002/j.1556-6676.1989.tb02131.x

Saygıll, S. (2004). Çocuklarda davranış bozuklukları. İstanbul: Elit Yayınları.

Silverberg, I. L. (2003). Bibliotherapy: thetherapeuticuse of didacticandliterarytexts in treatment, diagnosis, prevention, andtraining. The Journal of the American Osteopathic Association, 103(3),131-135.

Shechtman, Z. (1999) Bibliotherapy: an indirect approach to treatment of childhood aggression. Child Psychiatry and Human Development, 30(1), 39-53.

Starker, S. (1988). Psychologists and self-help books: attitudes and prescriptive practices of clinicians. American Journal Of Psychotherapy. 42 (3), 448-455.

Topçu, G. (2019). Okul öncesi dönem resimli çocuk kitaplarının psikolojik sağlamlık açısından incelenmesi.(Yayımlanmamış yüksek lisans tezi). Hacettepe Üniversitesi Sağlık Bilimleri Enstitüsü Çocuk Gelişimi Anabilim Dalı, Ankara.

Turan, L. (2005). Arkadaş edinme güçlüğü çeken çocukların problemlerini çözmede çocuk edebiyatı ürünlerinden yararlanma. Atatürk Üniversitesi Kazım Karabekir Eğitim Fakültesi Dergisi,12, 124-135.

Uzmen S., \& Mağden, D. (2002). Okulöncesi eğitim kurumlarına devam eden altı yaş çocuklarının prososyal davranışlarının resimli çocuk kitapları ile desteklenmesi. Atatürk Ĕ̆itim Fakültesi Ĕ̆itim Bilimleri Dergisi, $15,193-212$.

Yıldırım, A., \& Şimşek, H. (2011). Sosyal bilimlerde nitel araştırma yöntemleri. Ankara: Seçkin Yayıncılık.

\section{References of Reviewed Books}

Agee, J. (2018). The wall in the middle of the book. Resimleyen: Lily Malcom. (Çev.: E. Ü. Dal). İstanbul: Bkz Yayıncilik.

Artukmaç, Y., \& Ünsaldı Köle, R. (2018). Teo's book of night fear (4. basım). Resimleyen: Nurbanu Asena. Ankara: Bilgi Yayınevi Çocuk Kitaplığı.

Artukmaç, Y., \& Çakır, P. (2019). Teo's book of bullying (3. basım). Resimleyen: Nurbanu Asena. Ankara: Bilgi Yayınevi.

Artukmaç, Y., \& Çakır, P. (2019). Teo's poop book (27. basım). Resimleyen: Nurbanu Asena. Ankara: Bilgi Yayınevi.

Artukmaç, Y., \& Akgün, C. (2019). Teo'nun tırnak yeme kitabı (4. basım). Resimleyen: Nurbanu Asena. Ankara: Bilgi Yayınevi.

Artukmaç, Y., \& Akgün, C. (2019). Teo's mocking book (4. basım). Resimleyen: Nurbanu Asena. Ankara: Bilgi Yayınevi.

Artukmaç, Y., \& Sürücü, Ö. (2019). Teo's tablet book (4. basım). Resimleyen: Nurbanu Asena. Ankara: Bilgi Yayınevi.

Artukmaç, Y., \& Aydın, H. (2019). Teo's book of boredom (4. basım). Resimleyen: Nurbanu Asena. Ankara: Bilgi Yayınevi.

Bassi, S. (2017). My emotional world-4 I'm not afraid. (Çev.: K. Oğur). İstanbul: Dörtgöz Yayınları.

Bassi, S. (2017). My emotional world- 3 I'm not jealous. (Çev.: K. Oğur). İstanbul: Dörtgöz Yayınları.

Bassi, S. (2017). My emotional world- 8 I'm not alone (Çev.: K. Oğur). İstanbul: Dörtgöz Yayınları.

Bhadra, S. (2017). Semih's pet temper. Resimleyen: Marion Arbona. (Çev.: S. Özge). İstanbul: Kva Çocuk Sincap Yayincilik.

Bennett, H. J. (2019). It hurts when I poop! (4. baskı). İllüstrasyonlar: M.S. Weber. (Çev.: S. Yeniçeri). İstanbul: Okuyan Koala Okuyan Us. 
Brenifier, O. (2019). What is violence?. Resimleyen: Anne Hemstege. (Çev.: Z. B. Bölükbaşı) İzmir: Tudem.

Brenifier, O. (2020). Do I have the right to hit others? (2. bask1). Resimleyen: Anne Hemstege. (Çev.: Z. B. Bölükbaşı). İzmir: Tudem.

Craver, M. M. (2019). Chillax! (4. baskı). Resimleyen: Amerigo Pinelli. (Çev.:A. Erdem). İstanbul: Okuyan Koala Okuyan Us.

DePino, C. (2018). Blue cheese breath and stinky feet. Resimleyenler: Bonnie Mathews ve Charles Beyl. (Çev.: G. B. Baltacıoğlu). İstanbul: Okuyan Us Okuyan Koala Yayınları.

Ehrlin, C. J. F. (2019). The rabbit who wants to fall asleep (9. bask1). Illlüstrasyonlar: İrinaMaununen. (Çev.: S. Yeniçeri)., İstanbul: Okuyan Us Okuyan Koala.

Eland, E. (2018). When sadness comes to call. İstanbul: Martı Çocuk.

Holmes, M. M. (2019). A terrible thing happened (4. baskı). Resimleyen: Cary Pill. (Çev.: A. Erdem). İstanbul: Okuyan Koala Okuyan Us.

Kaur, H. (2015). Control your anger! Elif gets angry when she doesn't have money. (Çev.: K. Oğur). İstanbul: Dörtgöz Yayınları.

Levins, S. (2018). Ali's lie-o meter. İllüstrasyonlar: Jeff Ebbeler. (Çev.: G. B. Baltacıŏlu). İstanbul: Okuyan Us.

Morgan, M.(2018). Thank goodness for Bob. Resimleyen: Gabriel Alborozo. (Çev.: D. Erkan). Ankara: Binbir Çiçek Kitaplar.

Musgrove, M.(2019). The worry tree (14. baskı). (Çev.: D. B. Pinter). İstanbul: Altın Kitaplar Yayınevi.

Niner, H. L. (2015). I can't stop!-a story about tourette syndrome. Resimleyen: Meryl Treatner. (Çev.: Mine Özyurt Kılıç). Ankara: Tübitak.

Niner, H. L. (2015). Mr. worry a story about OCD. Resimleyen: Greg Swearingen. (Çev.: M. Özyurt Kılıç). Ankara: Tübitak.

Peterkin, A. (2019). The flyaway blanket (3. Baskı). Resimleyen: Emmeline Pidgen. (Çev.: G. B. Baltacioğlu). İstanbul: Okuyan Us Okuyan Koala Yayınları.

Pett, M., \& Rubinstein, G. (2018). The girl who doesn't make any mistakes (8. baskı). Resimleyen: Mark Pett. (Çev.: M. Özdemir). Ankara: Binbir Çiçek Kitaplar.

Polat, İ. (2018). I am discovering fear. Resimleyen: Gizem Korucu. İstanbul: Epsilon Yayınevi.

Ransom, J. F. (2018). Don't squeal unless ıt's a big deal (2. baskı). İllüstrasyonlar: Jackie Urbanoviç. (Çev.: S. Yeniçeri). İstanbul: Okuyan Koala Okuyan Us.

Redford, A. (2019). The boy who built a wall. Resimleyen: K. Simpson. (Çev.:H. Özdemir). İstanbul: Sola Kıdz Yayınları.

Sanna, F. (2018). Me and my fear. Resimleyen: Francesca Sanna. (Çev.: Z. Sevde). Ankara: Taze Kitap Yayıncılık.

Sileo, F. J. (2019). Selin sore loser (5. baskı). Resimleyen: Cary Pillo. (Çev.:A. Erdem). İstanbul: Okuyan Koala Okuyan Us.

Thompson, L. (2018). The goldfish boy. Resimleyen: Mike Lowery. (Çev.: Yelda Rasenfos). İstanbul: Pegasus Yayınları.

Weierbach, J., \& Phillips Hershey, E. (2019). Mind over basketball (4. baskı). Resimleyen: Charles Beyl. (Çev.: S. Yeniçeri). İstanbul: Okuyan Koala Okuyan Us. 